\title{
Identification of Clusters that Condition Resistance to Anthracnose in the Common Bean Differential Cultivars AB136 and MDRK
}

\author{
Ana Campa, ${ }^{\dagger}$ Noemí Trabanco, and Juan José Ferreira
}

First and third authors: Plant Genetics, Area of Horticultural and Forest Crops, SERIDA, Asturias, Spain; and second author: Division of Plant Production (DiSAA), Università degli Studi di Milano, Via Celoria 2, Milan (Italy). Accepted for publication 20 July 2017.

\begin{abstract}
The correct identification of the anthracnose resistance systems present in the common bean cultivars AB136 and MDRK is important because both are included in the set of 12 differential cultivars proposed for use in classifying the races of the anthracnose causal agent, Colletrotrichum lindemuthianum. In this work, the responses against seven $C$. lindemuthianum races were analyzed in a recombinant inbred line population derived from the cross AB136 $\times$ MDRK. A genetic linkage map of 100 molecular markers distributed across the 11 bean chromosomes was developed in this population to locate the gene or genes conferring resistance against each race, based on linkage analyses and $\chi^{2}$ tests of independence. The identified anthracnose resistance genes were organized in clusters. Two clusters were found in AB136: one located on linkage group $\mathrm{Pv} 07$, which corresponds to the anthracnose

resistance cluster Co-5, and the other located at the end of linkage group $\mathrm{Pv} 11$, which corresponds to the Co-2 cluster. The presence of resistance genes at the Co-5 cluster in AB136 was validated through an allelism test conducted in the $\mathrm{F}_{2}$ population $\mathrm{TU} \times \mathrm{AB} 136$. The presence of resistance genes at the $\mathrm{Co}-2$ cluster in $\mathrm{AB} 136$ was validated through genetic dissection using the $\mathrm{F}_{2: 3}$ population $\mathrm{ABM} 3 \times \mathrm{MDRK}$, in which it was directly mapped to a genomic position between 46.01 and $47.77 \mathrm{Mb}$ of chromosome Pv11. In MDRK, two independent clusters were identified: one located on linkage group Pv01, corresponding to the Co-1 cluster, and the second located on LG Pv04, corresponding to the Co-3 cluster. This report enhances the understanding of the race-specific Phaseolus vulgarisC. lindemuthianum interactions and will be useful in breeding programs.
\end{abstract}

Common bean (Phaseolus vulgaris L.) is an important grain legume for human consumption (http://www.fao.org/faostat/en/ \#home). This species is organized into two differentiated gene pools, Mesoamerican and Andean, with distinguishable morphologic and molecular characteristics (Bitocchi et al. 2013; Gepts and Bliss 1985; Kwak and Gepts 2009).

Anthracnose, caused by Colletotrichum lindemuthianum (Sacc. \& Magnus) Briosi \& Cavara, is a serious and widespread fungal disease that affects common bean (Schwartz et al. 2005). The fungus has a high pathogenic variability that is classified into physiological races based on the response profile of a standardized set of 12 differential common bean cultivars. A binary value is assigned to each cultivar and the race is named as the sum of the values of all susceptible cultivars (Pastor-Corrales 1991). More than 100 different races have been reported worldwide using this system (Mahuku and Riascos 2004; Mota et al. 2016; Sharma et al. 1999; Sicard et al. 1997). Some races are widely dispersed, such as race 73 , whereas other races are specific to certain countries or regions (Balardin et al. 1997). In northern Spain, races 3, 6, 19, 38, and 102 were identified, among which race 38 was the most prevalent (Ferreira et al. 2008).

The $P$. vulgaris $-C$. lindemuthianum interaction is very specific and can be considered as a reference model for studying racespecific resistance in plants. The first anthracnose resistance genes were described based on the interpretations of allelism tests (Barrus 1911; Fouilloux 1976). At present, more than 20 resistances genes (named as $\mathrm{Co}$; $\mathrm{Co}-1$ to $\mathrm{Co}-17$, and $\mathrm{Cou}$ to $\mathrm{Coz}$ ) have been described in common bean. Most of these genes show complete dominance and have been located in the genetic map of common bean organized in clusters of closely linked genes. Seven main

†Corresponding author: A. Campa; E-mail: acampa@serida.org

*The $\boldsymbol{e}$-Xtra logo stands for "electronic extra" and indicates that two supplementary tables are published online.

(c) 2017 The American Phytopathological Society anthracnose resistance clusters have been identified in linkage groups (LG) Pv01, Pv02, Pv03, Pv04, Pv07, Pv08, and Pv11 (Ferreira et al. 2013; Trabanco et al. 2015).

The anthracnose differential cultivar set has been a valuable source of resistance genes for breeding purposes. However, there is still a lack of information and several contradictions in the literature regarding the resistance genes present in some of these cultivars. The differential 'AB136' was first described by Schwartz et al. (1982) as a potential anthracnose resistance source included in the Mesoamerican gene pool. Despite the importance of this cultivar, its anthracnose resistance system has not been clearly established. A dominant resistance gene identified as Co-6 (Young and Kelly 1996), and a recessive gene identified as $c o-8$ (Alzate-Marin et al. 1997) have been reported in AB136, although the existence of a recessive gene has never been confirmed. The differential 'Michigan Dark Red Kidney' (MDRK) belongs to the Andean gene pool and was first described by Yerkes and Ortiz (1956). Thus far, the only anthracnose resistance gene described in MDRK was Co-1 (Kelly and Vallejo 2004; Melotto and Kelly 2000); therefore, this cultivar has been widely used in allelism tests to confirm the presence of this gene in other cultivars. However, some evidence suggests that anthracnose resistance in MDRK could be controlled by other loci apart from Co-1 (Campa et al. 2009).

This work further analyzed the genetic control of anthracnose resistance in the two important common bean differential cultivars AB136 and MDRK. The resistance to seven C. lindemuthianum races was analyzed in a recombinant inbreed line (RIL) population derived from the cross AB136 $\times$ MDRK (ABM RIL population), for which a linkage map was developed. An allelism test and a genetic dissection were additionally conducted using $\mathrm{F}_{2}$ and $\mathrm{F}_{2: 3}$ populations to validate the results obtained in the ABM RIL population.

\section{MATERIALS AND METHODS}

Plant material. The following three different populations were developed in this work. (i) A mapping population formed by $110 \mathrm{~F}_{7}$ 
RIL was obtained from the cross AB136 $\times$ MDRK $(A B M$ RIL population) using the single-seed descent method from individual $\mathrm{F}_{2}$ plants (Fehr 1987). (ii) A population of $122 \mathrm{~F}_{2}$ seeds was obtained from the cross ' $\mathrm{TU}$ ' $\times \mathrm{AB} 136$. $\mathrm{TU}$ is one of the 12 anthracnose differential cultivars in which the Co-5 gene was first described (Fouilloux 1976) and mapped on LG Pv07 (Campa et al. 2009). (iii) A population of $97 \mathrm{~F}_{2: 3}$ families was obtained from the cross between RIL ABM3 and MDRK. In this case, $F_{2}$ seed were selfpollinated and individually harvested to generate the corresponding $\mathrm{F}_{2: 3}$ families. $\mathrm{F}_{3}$ seedlings were used to characterize the racespecific anthracnose reaction of the respective $F_{2}$ plant. In addition to $\mathrm{AB} 136, \mathrm{MDRK}$, and TU, the nine remaining differential cultivars were used to confirm the identity of the $C$. lindemuthianum races.

Inoculation procedure and disease scoring. Seven isolates classified in different races were used: races 73, 449, and 1545 from the collection of the Crop and Soil Sciences Department (Michigan State University) and races 3, 6, 19, and 38 from The Regional Agrifood Research and Development Service (SERIDA) collection. These races were chosen for this study based on the reaction of the parental lines: AB136 was resistant to races 3, 6, 19, 38, 73, and 449 and MDRK was resistant to races 73,449 , and 1545 . The inoculation procedure was conducted as described by Rodríguez-Suárez et al. (2007). Seedlings were evaluated after 7 to 9 days using a 1-to-9 scale, where 1 is no visible symptoms and 9 is very severely diseased or dead (Van Schoonhoven and Pastor-Corrales 1987). Seedlings with no visible symptoms (value 1) or showing small lesions on leaves and stems (values 2 or 3 ) were considered resistant (R), while seedlings with large sporulation lesions (values 4 to 8 ) or that died (value 9) were considered susceptible (S). From 8 to 10 seedlings per RIL and 16 to $20 \mathrm{~F}_{3}$ seedlings per $\mathrm{F}_{2: 3}$ family were evaluated for each race. RIL were classified as resistant or susceptible, and $F_{2: 3}$ families were classified as homozygous resistant or susceptible (all $\mathrm{F}_{3}$ seedlings showed the same parental phenotype) or heterozygous (the two parental phenotypes were detected). The response to each race was evaluated in two independent tests in the RIL and $F_{2: 3}$ populations. A third evaluation in the same way as described above was conducted for RIL or $\mathrm{F}_{2: 3}$ families that showed unclear classifications. RIL, $\mathrm{F}_{2}$ seedlings, and $\mathrm{F}_{2: 3}$ families were individually randomized over the whole climate room. In each test, the parental lines and the anthracnose differential cultivars were included as controls.

Resistance genes were tentatively named according to Ferreira et al. (2013) considering the relative position of the anthracnose resistance clusters (Co cluster), the name of the race (in superscript), followed by the bean genotype in which the resistance gene was identified.

Marker analyses. Genomic DNA was extracted from young trifoliate leaves of noninoculated plants (21- to 30-day-old plants) using the FastDNA kit (MP Biomedicals, Illkirch, France) following the supplier's instructions. Molecular markers based on polymerase chain reaction (PCR) analyses were used to build a genetic linkage map of the RIL and the $F_{2: 3}$ populations. A set of simple sequence repeat (SSR), insertion-deletion polymorphism (InDel) (Moghaddam et al. 2014), and sequence-characterized amplified region (SCAR) markers were selected based on their physical positions on the $P$. vulgaris genome v1 (GenBank assembly GCF_000499855.1). Among them, the following markers labeling the main anthracnose resistance clusters identified in common bean were included: markers CV5420314 and TGA1.1 labeling the Co-1 cluster on LG Pv01 (Gonçalves-Vidigal et al. 2011), Pvctt001 and 254-G15F labeling the Co-3 cluster on LG Pv04 (David et al. 2008, Rodríguez-Suárez et al. 2008), Phs and SCARZ20 labeling the Co-5 cluster on LG Pv07 (Campa et al. 2009), 78L17a labeling the Co-4 cluster on LG Pv08 (Trabanco et al. 2015), and SH13b labeling the Co-2 on LG Pv11 (Campa et al. 2014). Cluster Co-17, which was recently identified on LG Pv02 (Trabanco et al. 2015), was tagged with marker BM156. PCR amplifications were performed in a Verity Thermal Cycler (Applied Biosystems, Life Technologies, CA) in a final volume of $20 \mu 1$ solution containing $25 \mathrm{ng}$ of genomic DNA, $100 \mathrm{mM}$ Tris- $\mathrm{HCl}, 100 \mathrm{mM} \mathrm{KCl}$ (pH 8.3), $4 \mathrm{mM} \mathrm{MgCl}_{2}, 0.2 \mathrm{mM}$ each dNTP (Bioline, London), $0.2 \mu \mathrm{M}$ each primer, and $1.25 \mathrm{U}$ of Biotaq DNA polymerase (Bioline). Amplification products were resolved on $8 \%$ polyacrylamide gels with $1 \times$ Tris-borate EDTA buffer ( $89 \mathrm{mM}$ Tris, $89 \mathrm{mM}$ boric acid, and 2 mM EDTA), stained with SYBR safe (Invitrogen, Life Technologies, CA), and visualized under UV light.

The morphological trait of growth habit, controlled by the Fin, fin gene, was also included in the ABM genetic linkage map, recorded as indeterminate (FinFin) versus determinate (finfin) growth habit.

Genetic analyses. Goodness-of-fit of observed to expected ratios was tested by using $\chi^{2}$. MAPMAKER Macintosh software, version 2.0 (Lander et al. 1987), was used for the map construction with a $\log$ of the likelihood ratio threshold of 3.0 and a recombination fraction of 0.25 . The order of the markers was estimated based on multipoint compare, order, and ripple analyses. Distances between ordered loci (in centimorgans) were calculated using the Kosambi mapping function. LG were named according to Pedrosa-Harand et al. (2008). When the observed segregation suggested the presence of one resistance gene, it was directly included in the genetic map. When the segregation suggested the presence of more than one gene, $\chi^{2}$ tests of independence were used to test the association between the two categorical variables "segregation of a resistance" and "segregation of a molecular marker". A significant association suggested that the chromosomal region tagged with the molecular marker was involved in the genetic control of the resistance response. Significance thresholds were determined using Bonferroni correction from the $\alpha$ level of 0.05 (Bonferroni 1936).

\section{RESULTS}

Genetic linkage map. In total, 100 of the 175 molecular markers tested were polymorphic between AB136 and MDRK and were analyzed in the RIL population: 70 SSR markers, 23 SCAR, 6 InDel, and the morphological trait growth habit (Supplementary Table S1). The resulting map included a total of 11 LG with an average of 9 markers per LG (a minimum of 5 markers on LG Pv09 and a maximum of 12 markers on LG Pv04). The ratio of missing values was less than $10 \%$ for all loci. In total, 29 markers showed a deviated segregation from that expected for one locus. Distorted markers were concentrated in five chromosomal regions on LG Pv04, Pv05, Pv06, Pv10, and Pv11. In most cases distortions were due to an excess of the AB136 allele, except on LG Pv06, in which it was due to an excess of the MDRK allele. The resulting map covers $1,000.6$ centimorgans $(\mathrm{cM})$, with an average marker distance of $12.7 \mathrm{cM}$ (minimum 0.7 and maximum 44.4). The relative marker order obtained on each LG is indicated in Figure 1, and it is in agreement with the physical positions of the markers on the bean genome.

Resistance segregation in the ABM population. Seven C. lindemuthianum races were analyzed in the ABM RIL population (Table 1). Resistance segregation to races 3, 38, 449, and 1545 conformed to the $3: 1 \mathrm{R} / \mathrm{S}$ ratio expected for two independent genes in a RIL population. Resistance segregation to races 6,19 , and 73 fit the $7: 1 \mathrm{R} / \mathrm{S}$ ratio expected for three independent genes.

Cosegregation was observed between races 3 and 38 in 95 RIL (80 RIL were resistant against the two races, haplotype $\mathrm{R}^{3}-\mathrm{R}^{38}$, and 15 RIL were susceptible, haplotype $S^{3}-S^{38}$ ) and evidence of recombination was found in 9 lines (4 RIL showing the haplotype $\mathrm{R}^{3}-\mathrm{S}^{38}$, and 5 showing the haplotype $\mathrm{S}^{3}-\mathrm{R}^{38}$ ). Thus, the genes conferring resistance against races 3 and 38 may be linked. Cosegregation was also observed between races 6 and 19 in 92 RIL (82 RIL were resistant against the two races, haplotype $\mathrm{R}^{6}-\mathrm{R}^{19}$, and 10 were susceptible, haplotype $\mathrm{S}^{6}-\mathrm{S}^{19}$ ), and evidence of recombination was found in 8 cases (3 RIL showing the haplotype $\mathrm{R}^{6}-\mathrm{S}^{19}$ and 5 showing the haplotype $S^{6}-R^{19}$ ). This result suggested a linkage between the genes conferring resistance against races 6 and 19 . 
The $\chi^{2}$ tests of independence. Histograms representing the probabilities obtained for each $\chi^{2}$ test of independence performed between each race and each molecular marker are provided in Figure 1. There were significant associations with markers located on LG Pv01, Pv04, Pv07, Pv10, and Pv11.

Races 3 and 38. Considering the response to race $3, \chi^{2}$ values showed significant associations with the markers located on LG Pv07 that labeled the Co-5 cluster, and with the markers located on LG Pv11 that labeled the Co-2 cluster (Fig. 1). Therefore, the two independent genes from AB136 that appeared to be involved in the control of resistance against race 3 (Table 1) could be located one at the Co-5 cluster position and the other at the Co- 2 cluster position (these genes are tentatively named $\mathrm{Co}-5^{3-A B 136}$ and $\mathrm{Co}-2^{3-A B 136}$ ) (Fig. 2A). According to Figure 1 and based on the cosegregation observed between races 3 and 38 , the same situation was determined for the response to race 38 (genes $C o-5^{38-A B 136}$ and $C o-2^{38-A B 136}$ ) (Fig. 2A).

Races 6 and 19. For race 6 , the $\chi^{2}$ values showed significant associations with the markers labeling the Co-5 cluster on LG Pv07 (Fig. 1), which suggested the presence of one resistance gene
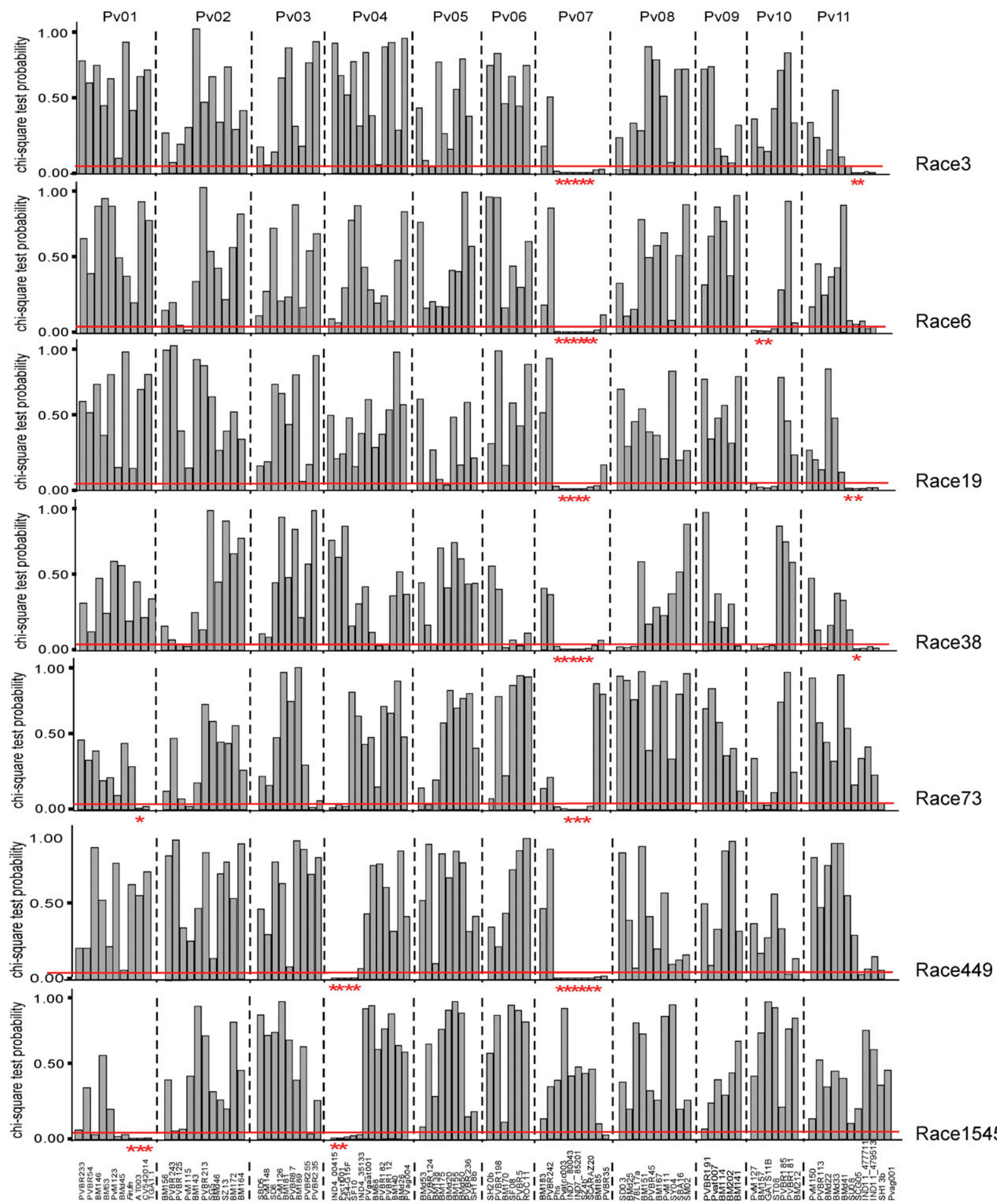

Race1545

Fig. 1. Histograms showing the probability of the $\chi^{2}$ test obtained between the response to a specific race and each loci included in the genetic map. In each linkage group, markers are represented according to the order obtained in the linkage map (left-hand side corresponds to $0 \mathrm{Mb}$ of the chromosome and right-hand side corresponds to final position). Asterisks represent significant associations after Bonferroni correction $(P<0.001)$. Dark line represents a significance level of $P=0.05$. 
against race 6 at this cluster (Co-56-AB136) (Fig. 2A). A significant association was also observed with the markers of LG Pv10, although this result should be carefully considered because most of the markers forming the LG PV10 did not fit the expected segregation ratio for one locus. The third resistance gene suspected to be involved based on the segregation ratio (Table 1) was not clearly identified by the $\chi^{2}$ analysis, although low probability values $(0.05<P>0.001)$ were observed when compared with markers that labeled the Co- 2 cluster on LG Pv11. For race 19, $\chi^{2}$ tests showed significant associations when compared with the markers that labeled the Co-5 cluster on LG Pv07 and the Co-2 cluster on LG Pv11 (Fig. 1), suggesting the presence of two independent resistance genes (Co-519-AB136 and Co-219-AB136) (Fig. 2A). The third resistance gene suspected to be involved based on the segregation ratio (Table 1) was not clearly identified by the $\chi^{2}$ analysis, although low probability values $(0.05<P>0.001)$ were also observed when compared with those of the markers on LG Pv10.

Race 1545. In this case, $\chi^{2}$ tests showed significant associations with the markers labeling the Co-1 and Co-3 clusters (Fig. 1). In

TABLE 1. Segregations observed for resistance to seven Colletrotrichum lindemuthianum races in the $\mathrm{AB} 136 \times \mathrm{MDRK}(\mathrm{ABM})$ recombinant inbred line (RIL) population ${ }^{\mathrm{a}}$

\begin{tabular}{|c|c|c|c|c|c|c|c|c|c|}
\hline \multirow[b]{3}{*}{ Race } & & & \multicolumn{4}{|c|}{ ABM RIL population } & \multirow[b]{3}{*}{ Ratio $^{\mathrm{c}}$} & \multirow[b]{3}{*}{$\chi^{2}$} & \multirow[b]{3}{*}{$P$} \\
\hline & \multicolumn{2}{|c|}{ Parent ${ }^{\mathrm{b}}$} & \multicolumn{2}{|c|}{ Observed } & \multicolumn{2}{|c|}{ Expected } & & & \\
\hline & AB136 & MDRK & $\mathrm{R}$ & $\mathrm{S}$ & $\mathrm{R}$ & $S$ & & & \\
\hline 3 & $\mathrm{R}$ & $S$ & 86 & 20 & 79.5 & 26.5 & $3: 1$ & 2.13 & 0.14 \\
\hline 6 & $\mathrm{R}$ & $S$ & 92 & 18 & 96.3 & 13.7 & $7: 1$ & 1.50 & 0.22 \\
\hline 19 & $\mathrm{R}$ & $S$ & 89 & 15 & 91.0 & 13.0 & $7: 1$ & 0.35 & 0.55 \\
\hline 38 & $\mathrm{R}$ & $\mathrm{S}$ & 87 & 21 & 81.0 & 27.0 & 3:1 & 0.78 & 0.18 \\
\hline 73 & $\mathrm{R}$ & $\mathrm{R}$ & 97 & 9 & 92.7 & 13.3 & $7: 1$ & 1.56 & 0.21 \\
\hline 449 & $\mathrm{R}$ & $\mathrm{R}$ & 74 & 33 & 80.3 & 26.7 & 3:1 & 1.95 & 0.16 \\
\hline 1545 & $S$ & $\mathrm{R}$ & 82 & 23 & 78.7 & 26.3 & $3: 1$ & 0.54 & 0.46 \\
\hline
\end{tabular}

a Segregation ratio tested in each case, and $\chi^{2}$ goodness-of-fit test are indicated. $\mathrm{R}=$ resistant and $\mathrm{S}=$ susceptible.

b Parental phenotype.

c Ratio 3:1 R/S expected for two independent genes in a RIL population and ratio 7:1 R/S expected for three independent genes in a RIL population. agreement with the results shown in Table 1, the presence of two independent genes against race 1545 in MDRK were deduced: one located at the Co-1 cluster on LG Pv01 and the second at the Co-3 cluster on LG Pv04 (genes Co-11545-MDRK and Co-31545-MDRK) (Fig. 2A).

Race 73. For race 73, significant associations were observed with the markers that labeled the Co-5 cluster on LG Pv07 and the Co-1 cluster on LG Pv01 (Fig. 1). The third resistance gene suspected to be involved based on the segregation ratio (Table 1) was not clearly identified by the $\chi^{2}$ analysis, although low probability values $(0.05<P>0.001)$ were observed when compared with markers labeling the $\mathrm{Co}-3$ cluster. Thus, the presence of one resistance gene against race 73 at the Co-5 cluster on LG Pv07, probably from $\mathrm{AB} 136$, and a second gene at the Co-1 cluster on LG Pv01, probably from MDRK, was concluded (genes $C o-5^{73-A B 136}$ and $C o-1^{73-M D R K}$ ) (Fig. 2A).

Race 449. Results of the $\chi^{2}$ tests of independence showed significant associations with the markers that labeled the Co-5 and Co-3 clusters (Fig. 1). It was concluded that one resistance gene was located at the Co-5 resistance cluster on LG Pv07, probably from $\mathrm{AB} 136$, and the second gene was located at the Co-3 cluster on LG Pv04, probably from MDRK (genes Co-5449-AB136 and Co-3449-MDRK) (Fig. 2A).

Allelism test. To verify the presence of a resistance gene in AB136 located at the Co-5 cluster, an allelism test was conducted using the $\mathrm{F}_{2}$ population $\mathrm{TU} \times \mathrm{AB} 136$. This allelism test was conducted using race 38 because, in the differential TU, a gene conferring resistance to race 38 was mapped on LG Pv07 at the Co-5 cluster (Campa et al. 2009). In total, $122 \mathrm{~F}_{2}$ plants derived from the cross $\mathrm{TU} \times \mathrm{AB} 136(\mathrm{R} \times \mathrm{R}$ cross $)$ were inoculated with race 38 and all of them showed a resistance response.

Genetic dissection. To validate the presence of resistance genes at the Co-2 cluster in AB136, a genetic dissection was performed using the $\mathrm{F}_{2: 3}$ population $\mathrm{ABM} 3 \times \mathrm{MDRK}$. The $\mathrm{ABM} 3$ RIL from the ABM population was selected according to its specific genetic combination, which was based on the resistance profile and genotype for specific markers. Line ABM3 was susceptible to race 449 and showed the MDRK genotype for markers that labeled the Co-5 cluster (markers Phs, Pvatcc003, IND7_80043, IND7_85201,
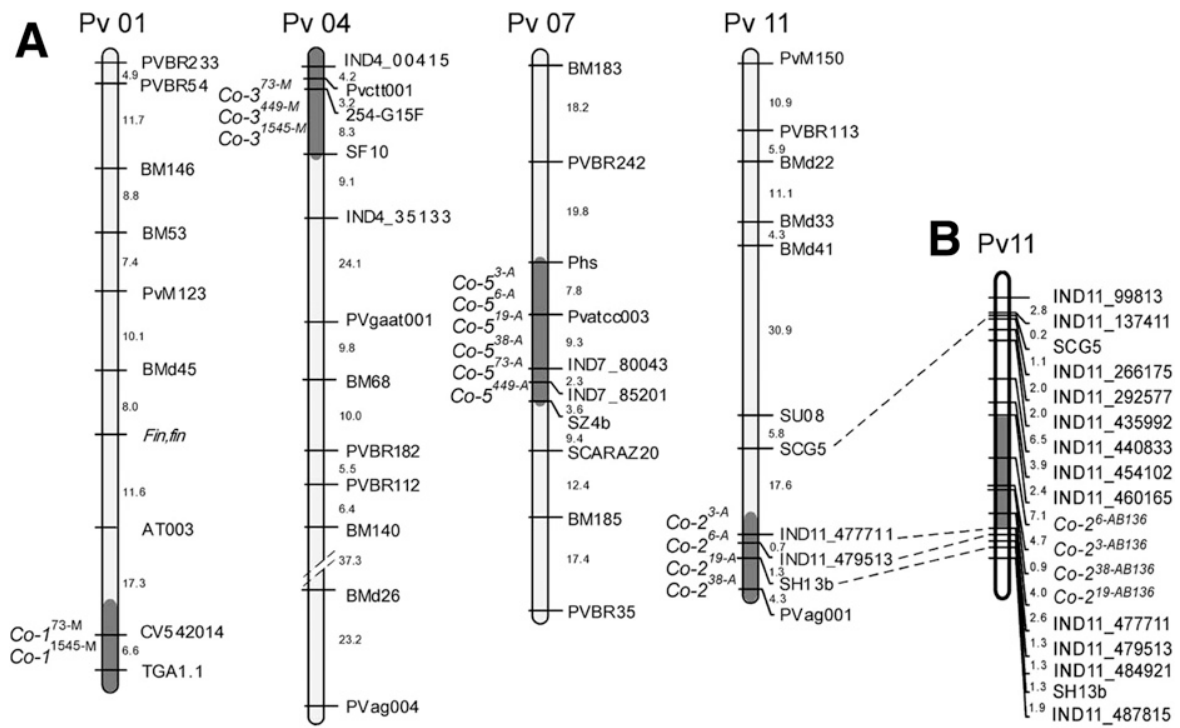

Fig. 2. A, Linkage groups (LG) Pv01, Pv04, Pv07, and Pv11 in which anthracnose resistance genes were indirectly located using the AB136 $\times$ MDRK recombinant inbred line population. Resistance genes are named by using their location in the genetic map (Co-anthracnose resistance cluster), name of the isolate or race (in superscript), followed by the bean genotype in which the resistance gene was identified $(\mathrm{A}=\mathrm{AB} 136$ and $\mathrm{M}=\mathrm{MDRK})$. Map distances are expressed in centimorgans, estimated using the Kosambi mapping function. Fin = locus controlling indeterminate versus determinate growth habit. B, LG Pv11 in which four anthracnose resistance genes were directly mapped using the $\mathrm{F}_{2: 3}$ population ABM3 $\times$ MDRK. Map distances are expressed in centimorgans, estimated using the Kosambi mapping function. 
SZ04, and SCARAZ20). Thus, this line was expected to lack resistance genes from $\mathrm{AB} 136$ at $\mathrm{Co}-5$. In addition, this line was resistant to races $3,6,38$, and 19 , indicating that other resistance genes from $\mathrm{AB} 136$ were present in $\mathrm{ABM} 3$. The segregation ratios for resistance to five $C$. lindemuthianum races in the $\mathrm{F}_{2: 3}$ population ABM3 $\times$ MDRK are shown in Table 2. Line ABM3 was resistant to four of the five races tested, whereas line MDRK was resistant to only one race. Resistance segregation to races 3, 38, and 19 fit the $1: 2: 1 \mathrm{R}-\mathrm{R} / \mathrm{S}-\mathrm{S}$ ratio expected for one locus. For race 6 , a slight deviation from the 1:2:1 R-R/S-S ratio was observed, due to a lack of homozygous resistant $F_{2: 3}$ families. However, this is the best fit for race 6 and the linkage map obtained support the possibility that resistance to race 6 in this population may be determined by one gene. Resistance segregation to race 73 (ABM3 susceptible $\times$ MDRK resistant) fit a 7:8:1 R-R/S-S ratio, indicating that two independent genes conferred resistance against race 73 in MDRK.

To determine more accurate localizations of these resistance genes, 16 molecular markers were analyzed in the ABM3 $\times$ MDRK population (Supplementary Table S2). The genes conferring resistance against races $3,6,19$, and 38 were directly mapped on LG Pv11 (Fig. 2B), forming a cluster of closely linked genes (Co-23-AB136, Co-26-AB136, $\mathrm{Co}-2^{19-A B 136}$, and $\left.\mathrm{Co}-2^{38-A B 130}\right)$. The physical position of this cluster, between 46.01 Mb (marker IND11_460165) and 47.77 Mb (marker IND11_477711) of chromosome Pv11, corresponded to that of cluster $\mathrm{Co}-2$. For race 73 , its segregation revealed the presence of more than one gene (Table 2). Thus, the localization of these resistance genes was investigated using $\chi^{2}$ tests of independence. Results revealed a significant association of the resistance with both markers CV542014 and SF10 that labeled the Co-1 and Co-3 clusters, respectively (CV542014-race 73: $\chi^{2}=$ 16.38 and $P=0.00$; SF10-race 73: $\chi^{2}=9.95$ and $P=0.01$ ). According to these results, two independent genes conferred resistance against race 73 in MDRK and they were probably located at clusters Co-1 and Co-3.

\section{DISCUSSION}

Results obtained in this work indicated that anthracnose racespecific resistance genes in $\mathrm{AB} 136$ are located in at least two independent chromosomal regions on LG Pv07 and Pv11. On LG Pv07, the genes conferring specific resistance against races 3, 6, 19, 38,73 , and 449 were located between markers Phs and SCARAZ20. The presence of anthracnose resistance genes in AB136 on LG Pv07 is well documented in the literature. In analyzing different $\mathrm{F}_{2}$ populations, monogenic segregations against races $23(\Delta), 31(\kappa)$, $64,69,73,81$, and 89 were detected in AB136 (Alzate-Marin et al. 1997, 1999, 2000; Gonçalves-Vidigal et al. 1997, 2001; Poletine et al. 2000). Random amplified polymorphic DNA (RAPD) marker OPZ04 $_{560}$ was linked to resistance genes against races $64,73,81$, and 89 (Alzate-Marin et al. 1999). In other mapping populations, this RAPD marker, and the corresponding SZ04 SCAR marker (Queiroz et al. 2004), were located on LG Pv07 (Freyre et al. 1998; Rodríguez-Suárez et al. 2007). The gene conferring specific resistance against race 89 in AB136 was also linked to RAPD marker OPAZ20 $0_{940}$ in the $\mathrm{F}_{2: 3}$ population 'Rudá' $\times \mathrm{AB} 136$ (Alzate-Marin et al. 2000), and the corresponding SCAR marker SCARZ20 (Queiroz et al. 2004) was mapped on LG Pv07 (Campa et al. 2009). Subsequently, specific resistance genes against races 81 and 449 were mapped on LG Pv07 linked to markers SCARAZ20 and SZ04 using the $\mathrm{F}_{2: 3}$ population AB136 × 'Michelite' (Campa et al. 2007). This locus present in AB136 on LG Pv07 was identified as the Co-6 gene (Young and Kelly 1996), although the genetic analyses were conducted using 'Catrachita' derived from AB136 ('BAT1225' $\times$ AB136). Results of an allelism test indicated that the gene present in Catrachita, which was thought to be Co-6, was independent from the Co-5 gene described in TU (Fouilloux 1976). $\mathrm{Co}-5$ in TU was identified as a cluster of genes protecting against races $3,6,7,38,39,102$, and 449, located on LG Pv07 between markers Phs and SCARAZ20 (Campa et al. 2009). The cluster of AB136 identified in this work on LG Pv07 has the same relative position to that of the Co-5 cluster described in TU. On the other hand, no segregation was found in the allelism test conducted with race 38 in the $F_{2}$ population $\mathrm{TU} \times \mathrm{AB} 136$. According to this evidence, the cluster identified in this work on LG Pv07 in AB136 corresponds to Co-5.

On LG Pv11, four resistant genes against races 3, 6, 19, and 38 derived from AB136 were mapped through genetic dissection. These genes were closely linked, forming a cluster between physical positions 46.01 and $47.77 \mathrm{Mb}$. This position on LG Pv11 corresponds to $\mathrm{Co}-2$, a gene widely deployed in common bean breeding programs (Ferreira et al. 2012, 2017; Kelly and Vallejo 2004). This chromosomal region has been identified as an important and complex cluster of resistance genes, which includes genes that protect against diseases other than anthracnose (Hurtado-Gonzales et al. 2017; Meziadi et al. 2016; Schmutz et al. 2014). This is the first report that identifies $\mathrm{Co}-2$ as a cluster involved in the genetic control of anthracnose resistance in the AB136 differential cultivar.

In addition to Co-5 and Co-2, segregation data obtained for races 6 and 19 suggested the presence of a third independent anthracnose resistance locus in AB136. Results of $\chi^{2}$ tests of independence revealed a significant association between race 6 and markers GATS11B and BM157, which were closely linked on LG Pv10. The GATS11B marker labeled a chromosomal region identified as a resistant gene analog region related to a minor gene contributing to partial resistance to anthracnose isolate 5DOM (López et al. 2003). Recently, data obtained from genome-wide association study (GWAS) analyses in a diversity panel of 230 Andean bean lines identified a region in chromosome Pv10 that was involved in moderate levels of resistance to anthracnose race 7 (Zuiderveen et al. 2016). On the other hand, the recent sequencing and assembled of the common bean genome (Schmutz et al. 2014) revealed the existence of a cluster of resistant-related genes at the end of chromosome Pv10. Thus, the localization of anthracnose resistance genes on chromosome Pv10 would not be unexpected. However, the data obtained in this work were not conclusive and should be carefully interpreted because most of the molecular markers analyzed for LG Pv10 showed deviations from the segregation ratio expected for one locus, with an excess of the AB136 allele. The preferential transmission of Mesoamerican alleles was described in common bean in crosses between the two gene pools (Paredes and Gepts 1995). Higher frequencies of distorted markers are expected in RIL populations derived through single-seed descent, in which distorted segregation represents the cumulative effect of both genetic and environmental factors on multiple generations (Paredes and Gepts 1995).

TABLE 2. Segregations observed for resistance to six Colletrotrichum lindemuthianum races in the $\mathrm{F}_{2: 3}$ population $\mathrm{ABM} 3 \times \mathrm{MDRK}^{\mathrm{a}}$

\begin{tabular}{|c|c|c|c|c|c|c|c|c|c|c|}
\hline \multirow[b]{3}{*}{ Race } & & & \multicolumn{6}{|c|}{$\mathrm{F}_{2: 3}$ families ABM $3 \times \mathrm{MDRK}^{\mathrm{b}}$} & \multirow[b]{3}{*}{$\chi^{2 \mathrm{~d}}$} & \multirow[b]{3}{*}{$P$} \\
\hline & \multicolumn{2}{|c|}{ Parent $\mathrm{t}^{\mathrm{c}}$} & \multicolumn{3}{|c|}{ Observed } & \multicolumn{3}{|c|}{ Expected } & & \\
\hline & ABM3 & MDRK & $\mathrm{R}$ & $\mathrm{R} / \mathrm{S}$ & $\mathrm{S}$ & $\mathrm{R}$ & $\mathrm{R} / \mathrm{S}$ & $\mathrm{S}$ & & \\
\hline 3 & $\mathrm{R}$ & $\mathrm{S}$ & 15 & 35 & 21 & 17.75 & 35.50 & 17.75 & 1.03 & 0.60 \\
\hline 6 & $\mathrm{R}$ & $\mathrm{S}$ & 11 & 47 & 26 & 21.00 & 42.00 & 21.00 & 6.55 & 0.04 \\
\hline 19 & $\mathrm{R}$ & $S$ & 18 & 28 & 18 & 16.00 & 32.00 & 16.00 & 1.00 & 0.61 \\
\hline 38 & $\mathrm{R}$ & S & 20 & 35 & 19 & 18.50 & 37.00 & 18.50 & 0.24 & 0.89 \\
\hline 73 & $\mathrm{~S}$ & $\mathrm{R}$ & 20 & 27 & 6 & 13.25 & 26.50 & 13.25 & 2.63 & 0.27 \\
\hline
\end{tabular}

a The segregation ratio considered in each case and the $\chi^{2}$ goodness-of-fit test is indicated. $\mathrm{R}=$ resistant and $\mathrm{S}=$ susceptible.

b $\mathrm{R}=\mathrm{F}_{3}$ families having all individuals resistant, $\mathrm{R} / \mathrm{S}=\mathrm{F}_{3}$ families having resistant and susceptible individuals, and $\mathrm{S}=\mathrm{F}_{3}$ families having all individuals susceptible.

${ }^{c}$ Parental phenotypes.

${ }^{d}$ For races 3, 6, 19, and 38 the ratio was 1:2:1 R:heterozygous:S expected for one locus. For race 73, the ratio was 7:8:1 R:heterozygous:S expected for two independent genes. 
For the differential MDRK, two chromosomal regions containing race-specific resistance genes were located on LG Pv01 and Pv04. On LG Pv01, genes conferring specific resistance against races 73 and 1545 were located in a position corresponding to cluster Co-1. On LG Pv04, genes conferring specific resistance against races 73 , 449, and 1545 were located in a position corresponding to cluster Co-3. Results obtained in this work for races 1545 and 449 are in agreement with those obtained for these races in the $\mathrm{F}_{2: 3}$ population TU $\times$ MDRK (Campa et al. 2009). Resistance to race 73 was analyzed in the $\mathrm{F}_{2: 3}$ population $\mathrm{ABM} 3 \times \operatorname{MDRK}(\mathrm{S} \times \mathrm{R}$ cross $)$ and the segregation observed fit the expected ratio for two independent genes from MDRK located at the Co- 1 and Co-3 clusters. As far as we know, this is the first $\mathrm{S} \times \mathrm{R}$ cross conducted to study the resistance against race 73 in MDRK, although it is a more appropriate type of cross for inferring the number and mode of action of genes that confer resistance. To date, resistance to race 73 in MDRK has been assumed to be conditioned only by the Co- 1 cluster, and it has been widely used in allelism tests in $\mathrm{R} \times \mathrm{R}$ crosses. For instance, using the $\mathrm{F}_{2}$ population MDRK $\times$ 'Perry Marrow' $(\mathrm{R} \times \mathrm{R}$ cross), a lack of segregation (all seedlings resistant) was observed for race 73 , which was interpreted as the $\mathrm{Co}-1$ gene conditioning resistance to race 73 in Perry Marrow (Melotto and Kelly 2000). However, based on the results of the present work, the resistance to race 73 in Perry Marrow could be conditioned by Co-1, Co-3, or both. In the $\mathrm{F}_{2}$ population MDRK $\times$ 'SEL 1308' $\mathrm{R} \times \mathrm{R}$ cross), the segregation ratio obtained for race 73 was interpreted as a $15: 1 \mathrm{R} / \mathrm{S}$ segregation ratio $\left(73: 2 \mathrm{R} / \mathrm{S} ; \chi^{2}=1.81, P=0.18\right)$ corresponding to the presence of two independent genes, one from MDRK and one from SEL1308 (Young et al. 1998). Nevertheless, this ratio also fit a $63: 1 \mathrm{R} / \mathrm{S}$ segregation ratio corresponding to three independent genes $\left(\chi^{2}=0.59, P=0.44\right)$ and could be reinterpreted based on the results obtained here. The genetic base for resistance against race 73 was recently analyzed by GWAS and significant associations with SNP markers ss715645251 on chromosome Pv01 and ss715649432 on chromosome Pv04 were identify (Zuiderveen et al. 2016), which is in accordance with the results obtained in this work. Resistance to race 73 in the differential MDRK could not be the most appropriate for an allelism test because it can be conditioned by two independent genes. However, when an allelism test is conducted, the genetic background should be considered, because anthracnose resistance genes showing a complementary mode of action have been described in common bean (Campa et al. 2011, 2014; Cardenas et al. 1964; Muhalet et al. 1981), more commonly in Andean genotypes such as MDRK; therefore, a different number of resistance genes could be identified in a genotype against the same race, depending on the type of cross (Ferreira et al. 2013).

Although RIL populations are more informative for studying complex segregation patterns than other types of populations, the size of the RIL population used in this work was not very large and the number of molecular markers used in the genetic map was limited. For these reasons, parts of the results interpreted from the RIL population were validated using complementary crosses and genetic dissection. These validations support the results obtained and endorse the use of $\chi^{2}$ tests of independence for the localization of major genes involved in complex segregations. Results obtained in this work can be relevant to the interpretation of future allelism tests and to the implementation of breeding programs focused on protecting bean crops against anthracnose.

\section{ACKNOWLEDGMENTS}

This work was partially financed by grant RTA2011-0076-CO2-01 from Instituto de Investigación y Tecnología Agraria y Alimentaria (INIA) Ministerio de Economía y Competitividad, Spanish Government and cofinanced with the European Regional Development's funds (FEDER). A. Campa is recipient of a salary from the INIA-CCAA (INIA-DR13-0222), Spain. We thank J. D. Kelly of Michigan State University for providing some of the isolates of C. lindemuthianum; and M. Bueno, J. A. Poladura, and M. Sanz for their technical assistance.

\section{LITERATURE CITED}

Alzate-Marin, A. L., Baia, G. S., de Paula, T. J., Jr., de Carvalho, G. A., de Barros, E. G., and Moreira, M. A. 1997. Inheritance of anthracnose resistance in common bean differential cultivar AB 136. Plant Dis. 81:996-998.

Alzate-Marin, A. L., Menarim, H., Chagas, J. M., de Barros, E. G., and Moreira, M. A. 2000. Identification of RAPD marker linked to Co-6 anthracnose resistance gene in common bean cultivar AB136. Genet. Mol. Biol. 23:633-637.

Alzate-Marin, A. L., Menarim, H., de Carballo, G. A., de Paula, T. J., Jr., de Barros, E. G., and Moreira, M. A. 1999. Improved selection with newly RAPD markers linked to resistance gene to four pathotypes of Colletotrichum lindemuthianum in common bean. Phytopathology 89: 281-285.

Balardin, R. S., Jarosz, A., and Kelly, J. D. 1997. Virulence and molecular diversity in Colletotrichum lindemuthianum from South, Central and North America. Phytopathology 87:1184-1191.

Barrus, M. F. 1911. Variation of cultivars of beans in their susceptibility to anthracnose. Phytopathology 1:190-195.

Bitocchi, E., Belluci, E., Giardini, A., Rau, D., Rodriguez, M., Biagetti, E., Santilocchi, R., Spagnoletti Zeuli, P., Gioia, T., Logozzo, G., Attene, G., Nanni, L., and Papa, R. 2013. Molecular analysis of the parallel domestication of the common bean (Phaseolus vulgaris) in Mesoamerica and the Andes. New Phytol. 197:300-313.

Bonferroni, C. E. 1936. Teoria statistica delle classi e calcolo delle probabilita. Pubbl. R Istituto Superiore Sci. Econ. Commer. Firenze 8:3-62.

Campa, A., Giraldez, R., and Ferreira, J. J. 2009. Genetic dissection of the resistance to nine different anthracnose races in the common bean differential cultivars MDRK and TU. Theor. Appl. Genet. 119:1-11.

Campa, A., Giraldez, R., and Ferreira, J. J. 2011. Genetic analysis of the resistance to eight anthracnose races in the common bean differential cultivar Kaboon. Phytopathology 101:757-764.

Campa, A., Pérez-Vega, E., Giraldez, R., and Ferreira, J. J. 2007. Inheritance of race-specific resistance to anthracnose in the differential cultivar AB136. Annu. Rep. Bean Improv. Coop. 50:87-88.

Campa, A., Rodríguez-Suárez, C., Giraldez, R., and Ferreira, J. J. 2014. Genetic analysis of the response to eleven Colletotrichum lindemuthianum races in a RIL population of common bean (Phaseolus vulgaris L.). BMC Plant Biol. 14:115.

Cardenas, F., Adams, M. W., and Andersen, A. 1964. The genetic system for reaction of field beans (Phaseolus vulgaris L.) to infection by three physiologic races of Colletotrichum lindemuthianum. Euphytica 13:178-186.

David, P., Sévignac, M., Thareau, V., Catillon, Y., Kami, J., Gepts, P., Langin, T., and Geffroy, V. 2008. BAC end sequences corresponding to the B4 resistance gene cluster in common bean: A resource for markers and synteny analyses. Mol. Genet. Genomics 280:521-533.

Fehr, W. R. 1987. Principles of cultivar development. Vol I: Theory and Technique. MacMillan Publishing Company, New York.

Ferreira, J. J., Campa, A., and Kelly, J. D. 2013. Organization of genes conferring resistance to anthracnose in common bean. Pages 151-181 in: Translational Genomic for Crop Breeding. R. Varshney and R. Tuberosa, eds. John Wiley \& Sons, Ltd., Chichester, UK.

Ferreira, J. J., Campa, A., Pérez-Vega, E., and Giraldez, R. 2008. Reaction of a bean germplasm collection against five races of Colletotrichum lindemuthianum identified in Northern Spain and implications for breeding. Plant Dis. 92:705-708.

Ferreira, J. J., Campa, A., Pérez-Vega, E., Rodríguez-Suárez, C., and Giraldez, R. 2012. Introgression and pyramiding into common bean market class fabada of genes conferring resistance to anthracnose and potyvirus. Theor. Appl. Genet. 124:777-788.

Ferreira, J. J., Murube, E., and Campa, A. 2017. Introgressed genomic regions in a set of near-isogenic lines of common bean revealed by genotyping-by sequencing. Plant Genome 10.

Fouilloux, G. 1976. L' anthracnose du haricot (Colletotrichum lindemuthianum Sacc. et Magn.): Nouvelles sources de resistance et nouvelles races physiologiques. Ann. Amelior. Plant. 26:443-453.

Freyre, R., Skroch, P. W., Geffroy, V., Adam-Blondon, A. F., Shirmohamadali, A., Johnson, W. C., Llaca, V., Nodari, R. O., Pereira, P. A., Tsai, S. M., Tohme, J., Dron, M., Nienhuis, J., Vallejos, C. E., and Gepts, P. 1998. Towards an integrated linkage map of common bean. 4. Development of a core linkage map and alignment of RFLP maps. Theor. Appl. Genet. 97: 847-856.

Gepts, P., and Bliss, F. A. 1985. $F_{1}$ hybrid weakness in the common bean: Differential geographic origin suggests two gene pools in cultivated bean germplasm. J. Hered. 76:447-450. 
Gonçalves-Vidigal, M. C., Cardoso, A. A., Vieira, C., and Saralva, L. S. 1997. Inheritance of anthracnose resistance in common bean genotypes PI 207262 and AB136. Braz. J. Genet. 20:59-62.

Gonçalves-Vidigal, M. C., Cruz, A. S., Garcia, A., Kami, J., Vidigal Filho, P. S., Sousa, L. L., McClean, P., Gepts, P., and Pastor-Corrales, M. A. 2011. Linkage mapping of the Phg-1 and $\mathrm{Co}^{-1^{4}}$ genes for resistance to angular leaf spot and anthracnose in the common bean cultivar AND 277. Theor. Appl. Genet. 122:893-903.

Gonçalves-Vidigal, M. C., Sakiyama, N. S., Vidigal Filho, P. S., Amaral, A. T., Jr., Poletine, J. P., and Oliveira, V. R. 2001. Resistance of common bean cultivar $\mathrm{AB} 136$ to races 31 and 69 of Colletotrichum lindemuthianum: The Co-6 locus. Crop Breed. Appl. Biotechnol. 1:99-104.

Hurtado-Gonzales, O. P., Valentini, G., Gilio, T. A. S., Martins, A. M., Song, Q., and Pastor-Corrales, M. A. 2017. Fine mapping of Ur-3, a historically important rust resistance locus in common bean. Genes, Genomes. Genetics 7:557-569.

Kelly, J. D., and Vallejo, V. A. 2004. A comprehensive review of the major genes conditioning resistance to anthracnose in common bean. HortScience 39:1196-1207.

Kwak, M., and Gepts, P. 2009. Structure of genetic diversity in the two major gene pools of common bean (Phaseolus vulgaris L., Fabaceae). Theor. Appl. Genet. 118:979-992.

Lander, E. S., Green, P., Abrahamson, J., Barlow, A., Daly, M. J., Lincoln, S. E., and Newburg, L. 1987. MAPMAKER: An interactive computer package for constructing primary genetic linkage maps of experimental and natural populations. Genomics 1:174-181.

López, C. E., Acosta, I. F., Jara, C., Pedraza, F., Gaitán-Solís, E., Gallego, G., Beebe, S., and Tohme, J. 2003. Identifying resistance gene analogs associated with resistances to different pathogens in common bean. Phytopathology 93:88-95.

Mahuku, G. S., and Riascos, J. J. 2004. Virulence and molecular diversity within Colletotrichum lindemuthianum isolates from Andean and Mesoamerican bean varieties and regions. Eur. J. Plant Pathol. 110:253-263.

Melotto, M., and Kelly, J. D. 2000. An allelic series at the Co-1 locus conditioning resistance to anthracnose in common bean of Andean origin. Euphytica 116:143-149.

Meziadi, C., Richard, M. M. S., Derquennes, A., Thareau, V., Blanchet, S., Gratias, A., Pflieger, S., and Geffroy, V. 2016. Development of molecular markers linked to disease resistance genes in common bean based on whole genome sequence. Plant Sci. 242:351-357.

Moghaddam, S. M., Song, Q., Mamidi, S., Schmutz, J., Lee, R., Cregan, P., Osorno, J. M., and McClean, P. E. 2014. Developing market class specific InDel markers from next generation sequence data in Phaseolus vulgaris L. Front. Plant Sci. 4:185.

Mota, S. F., Barcelos, Q. L., Dias, M. A., and Souza, E. A. 2016. Variability of Colletotrichum spp. in common bean. Genet. Mol. Res. 15:gmr.15027176.

Muhalet, C. S., Adams, M. W., Saettler, A. W., and Ghaderi, A. 1981. Genetic system for the reaction of field beans to beta, gamma, and delta races of Colletotrichum lindemuthianum. J. Am. Soc. Hortic. Sci. 106:601-604.

Paredes, O. M., and Gepts, P. 1995. Segregation and recombination in intergene pool crosses of Phaseolus vulgaris L. J. Hered. 86:98-106.

Pastor-Corrales, M. A. 1991. Estandarización de variedades diferenciales y designación de razas de Colletotrichum lindemuthianum. (Abstr.) Phytopathology 81:694.

Pedrosa-Harand, A., Porch, T., and Gepts, P. 2008. Standard nomenclature for common bean chromosomes and linkage groups. Annu. Rep. Bean Improv. Coop. 51:106-107.
Poletine, J. P., Gonçalves-Vidigal, M. C., Filho, P. S. V., Scampin, C. A., Silverio, L., and Tomazella, C. 2000. Inheritance of resistance to race 69 and 453 of Colletotrichum lindemuthianum in the common bean. Braz. Arch. Biol. Technol. 43:479-485.

Queiroz, V. T., de Sousa, C. S., Costa, M. R., Sanglad, D. A., Arruda, K. M. A., Oliveira de Souza, T. L. P., Ragagnin, V. A., Gonçalves de Barros, E., and Moreira, M. A. 2004. Development of SCAR markers linked to common bean angular leaf spot resistance genes. Annu. Rep. Bean Improv. Coop. 47: 237-239.

Rodríguez-Suárez, C., Ferreira, J. J., Campa, A., Pañeda, A., and Giraldez, R. 2008. Molecular mapping and intra-cluster recombination between anthracnose race specific resistance genes in the common bean differential cultivars Mexico 222 and Widusa. Theor. Appl. Genet. 116:807-814.

Rodríguez-Suárez, C., Méndez-Vigo, B., Pañeda, A., Ferreira, J. J., and Giraldez, R. 2007. A genetic linkage map of Phaseolus vulgaris L. and localization of genes for specific resistance to six races of anthracnose (Colletotrichum lindemuthianum). Theor. Appl. Genet. 114:713-722.

Schmutz, J., McClean, P. E., Mamidi, S., Wu, G. A., Cannon, S. B., Grimwood, J., Jenkis, J., Shu, S., Song, Q., Chavarro, C., Torres-Torres, M., Geffroy, V., Moghaddam, S. M., Gao, D., Abernathy, B., Barry, K., Blair, M., Brick, M. A., Chovatia, M., Gepts, P., Goodstein, D. M., Gonzales, M., Hellsten, U., Hyten, D. L., Jia, G., Kelly, J. D., Kudrna, D., Lee, R., Richard, M. M. S., Miklas, P. N., Osorno, J. M., Rodrigues, J., Thareau, V., Urrea, C. A., Wang, M., Yu, Y., Zhang, M., Wing, R. A., Cregan, P. B., Rokhsar, D. S., and Jackson, S. S. 2014. A reference genome for common bean and genome-wide analysis of dual domestications. Nat. Genet. 46: 707-713.

Schwartz, H. F., Steadman, J. R., Hall, R., and Forster, R. 2005. Compendium of Bean Diseases. 2nd Edition. American Phytopathology Society, St. Paul, MN.

Schwartz, H. F., Pastor-Corrales, M. A., and Singh, S. P. 1982. New sources of resistance to anthracnose and angular leaf spot of beans (Phaseolus vulgaris). Euphytica 31:741-754.

Sharma, P. N., Kumar, A., Sharma, O. P., Dud, D., and Tyagi, P. D. 1999. Pathogenic variability in Colletotrichum lindemuthianum and evaluation of resistance in Phaseolus vulgaris in the North-Western Himalayan region of India. J. Phytopathol. 147:41-45.

Sicard, D., Buchet, S., Michalakis, Y., and Neema, C. 1997. Genetic variability of Colletotrichum lindemuthianum in wild populations of common bean. Plant Pathol. 46:355-365.

Trabanco, N., Campa, A., and Ferreira, J. J. 2015. Identification of a New Chromosomal Region Involved in the Genetic Control of Resistance to Anthracnose in Common Bean. Plant Genome 8.

Van Schoonhoven, A., and Pastor-Corrales, M. A. 1987. Standard System for the Evaluation of Bean Germplasm. CIAT, Cali, Colombia.

Yerkes, W. D., and Ortiz, M. T. 1956. New races of Colletotrichum lindemuthianum in Mexico. Phytopathology 46:564-567.

Young, R. A., and Kelly, J. D. 1996. Characterization of the genetic resistance to Colletotrichum lindemuthianum in common bean differential cultivars. Plant Dis. 80:650-654.

Young, R. A., Melotto, M., Nodari, R. O., and Kelly, J. D. 1998. Marker assisted dissection of oligogenic anthracnose resistance in the common bean cultivar, G2333. Theor. Appl. Genet. 96:87-94.

Zuiderveen, G. H., Padder, B. A., Kamfwa, K., Song, Q., and Kelly, J. D. 2016. Genome-wide association study of anthracnose resistance in Andean beans (Phaseolus vulgaris). PLoS One 11:e0156391. 